\title{
Molecular representations of stereoisomers with chiral centers using molecular models in origami
}

\author{
Representaciones moleculares de estereoisómeros con centros quirales \\ mediante modelos moleculares en origami
}

\section{Representações moleculares de estereoisômeros com centros quirais utilizando modelos moleculares em origami}

\section{Diana Yicela Pineda Caro* | Edgar EduardoVargas Aguilar | Oswaldo Eliécer Cárdenas González Universidad Pedagógica y Tecnológica de Colombia, Tunja, Colombia}

- Fecha de recepción: 2019-02-08.

- Fecha concepto de evaluación: 2019-09-05.

- Fecha de aprobación: 2019-1/-05. http://dx.doi.org/ I0.22335/rlct.vl Ii2.829
Para citar este artículo / To reference this article / Para citar este artigo: Pineda Caro, D. Y., Vargas Aguillar, E. E., \& Cárdenas González, O.E. (2019). Molecular representations of stereoisomers with chiral centers using molecular models in origami. Revista Logos Ciencia \& Tecnología, I I (2), | 38- | 50. http://dx.doi.org/ |0.22335/rlct.v | Ii2.829

\section{SUMMARY}

The objective of this work was to bring the students closer to a real and three-dimensional structure of the matter, relating this characteristic with the physical and chemical properties of stereoisomeric molecules with chiral centers and checking the didactic transposition through molecular models made in origami. For the methodological development of the research, 101 Colombian students from the Pedagogical and Technological University from Colombia and the University from Boyacá participated, from the academic programs in Chemistry, Biology, Bachelor of Natural Sciences and Environmental Education and Physiotherapy. The results obtained show that the implementation of molecular models in origami strengthens visuospatial skills; in addition, the conceptual appropriation of stereoisomers and molecular representations.

Keyword: Molecular Model, origami, stereoisomerism, visospatial skills, didactic transposition 


\begin{abstract}
RESUMEN
Este trabajo tuvo por objetivo acercar los estudiantes a una estructura real y tridimensional de la materia, relacionando ésta característica con las propiedades físicas y químicas de moléculas estereoisoméricas con centros quirales y comprobar la transposición didáctica a través de modelos moleculares realizados en origami. Para el desarrollo metodológico de la investigación participaron I0I estudiantes colombianos de la Universidad Pedagógica y Tecnológica de Colombia y de la Universidad de Boyacá, de los programas académicos en Química, Biología, Licenciatura en Ciencias Naturales y Educación Ambiental y Fisioterapia. Los resultados obtenidos demuestran que la implementación de los modelos moleculares en origami fortalece las habilidades visoespaciales; además la apropiación conceptual sobre estereoisómeros y las representaciones moleculares.
\end{abstract}

Palabras Clave: Modelo Molecular, origami, estereoisomería, habilidades visoespaciales, transposición didáctica

\title{
SUMÁRIO
}

O objetivo deste trabalho foi aproximar os alunos de uma estrutura real e tridimensional do sujeito, relacionando essa característica com as propriedades físicas e químicas de moléculas estereoisoméricas com centros quirais e verificando a transposição didática através de modelos moleculares feitos em origami. Para o desenvolvimento metodológico da pesquisa, $10 \mathrm{I}$ estudantes colombianos da Universidade Pedagógica e Tecnológica da Colômbia e da Universidade de Boyacá participaram dos programas acadêmicos de Química, Biologia, Ciências Naturais e Educação Ambiental e Fisioterapia. Os resultados obtidos mostram que a implementação de modelos moleculares no origami fortalece as habilidades visoespaciais; além disso, a apropriação conceitual de estereoisômeros e representações moleculares.

Palavras-chave: Modelo Molecular, origami, stereoisomería, habilidades visoespaciais, transposição didática

The stereoisomers are compounds that have the same number of atoms and the same connectivity, but differ from the spatial distribution of them. According to Castro (2007), this characteristic influences the chemical and physical properties of compounds such as the melting point, dipole moment, nuclear magnetic resonance spectrum, chromatographic and crystallization behavior, being relevant in different fields of knowledge, such as organic chemistry, biochemistry, biology, pharmaceutical chemistry or industrial chemistry. Likewise, it is essential to highlight the importance of chiral compounds that may have different toxicological or biological properties, affecting the biochemical processes of living beings.

According to Pérez (2013), the importance of studying stereoisomers and chiral compounds, is that most of the biochemical processes of nature are stereospecific, there are enantiomers with different toxicological and biological properties, and in addition there are agrochemicals that have non-active enantiomers, which can be toxic to non-target organisms. Added to this, Castro (2007), highlight the importance of stereoisomers in the pharmacological industry, where there are enantiomers that can be toxic or beneficial for human or animal health, likewise, the $\mathrm{R}, \mathrm{S}$ configuration can also determine the biological effect of a medication, such is the case of Propanolol, whose $\mathrm{R}$ configuration, have a contraceptive effect, but for the $\mathrm{S}$ configuration, it is an anti-hypertensive.

The molecular structure of stereoisomers or chemical structures in general, can be studied with techniques such as X-rays and nuclear magnetic resonance (NMR), which are expensive to implement in higher education academic programs. For this reason, the elaboration of molecular models in origami was implemented, based on the papyroflexic model of Carbon, proposed by Garrido (2007), to carry out the transformation of scientific knowledge about stereoisomy that can be brought to the classroom as a knowledge teachable, following the theory of didactic transposition, proposed by Verret (1974), theory taken up and deepened by Chevellard (I99I). 
On the other hand, Fensham (2002) distinguishes as visospatial ability, the ability to perceive three-dimensional objects from two-dimensional representations, that is, the ability to change representations in different perspectives and the recognition of effects by rotation and reflection, in other words: visualization, orientation and operation. In accordance with the above, through the pedagogical reflection and the methodological development of the present investigation, a new concept arises that can be transcendental for future research: "atomic-molecular visospatial abilities", that is, the capacity in which Individuals interact with the spatial position of the submicroscopic structure of matter, not necessarily including a visual stimulus.

In consideration of the above, the present research had as main objective, to strengthen the teaching-learning processes on molecular representations of stereoisomers with chiral centers, using molecular models in origami. In addition, specific objectives were proposed, such as: identifying the previous knowledge that students have about molecular representations and stereoisomers, developing visuospatial skills through molecular modeling in origami and comparing the contributions of molecular modeling in origami, compared to the traditional teaching of stereoisomerism.

Regarding the methodological aspect, this research was developed in two Colombian universities, with 101 students of some academic programs such as: Chemistry, biology, Bachelor of Natural Sciences and Environmental Education, studying the subject of organic chemistry and for the physiotherapy program where the subject of biochemistry was being studied. Taking into account that the research followed quasi-experimental methodological design, the group of chemistry students was selected randomly as a control group and the others as experimental groups. The methodological phases were three: Phase I: Diagnosis, Phase II: Design and implementation of the didactic strategy and Phase III: Evaluation.

The results show that the didactic strategy used allowed the experimental groups to obtain a better frequency of satisfactory answers in the evaluated categories, unlike those of the control group. This allows us to consider that molecular models in origami facilitated an approach to the three-dimensional representations of matter; allowing in this way, explain, describe and predict spatial changes of the atoms that constitute organic molecules with stereogenic centers, through the acquisition of visospatial skills.

\section{Methodology}

This project was approached from the interpretive paradigm (Pérez, 2015), taking into account that it was intended to understand the parameters that regulate the teaching of stereoisomers and the implication of molecular models in origami, as a tool of didactic transposition. On the other hand, the approach is qualitative taking into account that it was based on an interpretative perspective centered on the understanding of the meaning of human actions, according to Hernández, Fernández and Baptista (20I0). The method used for the research was of the quasi-experimental type, with non-equivalent group design without pretest (Cook \& Campbell, 1979). This design is characterized because the assignment of the groups is not random; therefore, the equivalence of the groups is not guaranteed, likewise, several experimental groups can be used to which the experimental treatment is applied, but not to the control one. For the measurement, all the research group is applied a final test or post - test, according Briones (1998).

The population and sample of this research was chosen non-randomly and for convenience, taking into account the possibility of conducting the workshops in four groups of students who were studying subjects related to stereoisomeric content, in two of the most important Universities of Boyacá. The Pedagogical and Technological University of Colombia (UPTC), had three sample groups, the first group, consisting of students who were studying the subject of Organic Chemistry I, the program in Chemistry; the second, constituted by students who stu-died the subject in Biochemistry, of the program in Biology, and the third group, made up of students of the Organic Chemistry subject, of the Bachelor's Degree in Natural Sciences and Environmental Education. The University of Boyacá (UB), had a group, made up of students of the subject in biochemistry, of the physiotherapy program. In Table I, the research groups are characterized, relating for each of them the University, the program to which it belongs, the academic subject and semester and the number of students for each group.

Table I. Characterization of the population and sample.

\begin{tabular}{cccccc} 
Group & college & Program & Subject & Semester & $\begin{array}{c}\text { Number } \\
\text { of students }\end{array}$ \\
$\begin{array}{c}\text { Group } \\
\text { A }\end{array}$ & UPTC & Chemistry & $\begin{array}{c}\text { Organic } \\
\text { Chemistry }\end{array}$ & Second & 31 \\
$\begin{array}{c}\text { Group } \\
\text { B }\end{array}$ & UPTC & Biology & $\begin{array}{c}\text { Organic } \\
\text { Chemistry }\end{array}$ & Second & 30 \\
Group & UPTC & $\begin{array}{c}\text { Bachelor } \\
\text { of Natural } \\
\text { Sciences and } \\
\text { Environmental } \\
\text { Education }\end{array}$ & $\begin{array}{c}\text { Organic } \\
\text { Chemistry }\end{array}$ & Quarter & 20 \\
$\begin{array}{c}\text { Group } \\
\text { D }\end{array}$ & UB & $\begin{array}{c}\text { Physiotherapy } \\
\text { Biochem- } \\
\text { istry }\end{array}$ & Second & 20 \\
\hline
\end{tabular}

In table 2, the registration sequence for each of the groups that intervened in the methodology is related, where (-) means that it is not done and $(x)$ that it is done. 
Table 2. Methodological Record Sequence

\begin{tabular}{cccccc}
\multicolumn{5}{c}{ Registration Sequence } \\
Group & Pretest & Diagnosis & Treatment & Final test \\
\hline Group A & - & $\times$ & - & X \\
\hline Group B & - & $\times$ & $\times$ & $\times$ \\
Group C & - & $\times$ & $X$ & $\times$ \\
Group D & - & $X$ & $X$ & $\times$ \\
\hline
\end{tabular}

As a result of the quasi-experimental design proposed with non-equivalent groups without pretest, it should be clarified that for the research there was a control group (group A). Therefore, groups B, C and D were experimental.

\section{Procedure}

This investigation was carried out in three phases. In the first phase: "Diagnosis", a diagnostic test was developed for all the students of the groups under study, in order to know the previous knowledge about molecular representations, the concept of isomers and their difference with stereoisomers. The test consisted of five questions that describe two categories of evaluation: "Perceptions about molecular representations" and "Identification of molecular representations". Annex I contains the diagnostic test, where questions I and 5 correspond to the first category and questions 2, 3 and 4, to the second category.

The second phase: "design and implementation of the teaching strategy", in which a tutorial was designed activities molecular modeling using the origami technique, distributed to guide four class sessions, each with a intensity two hours. The guide was used only with the experimental groups, for the control group the same number of workshops was oriented, from a traditional teaching approach (see figure I).

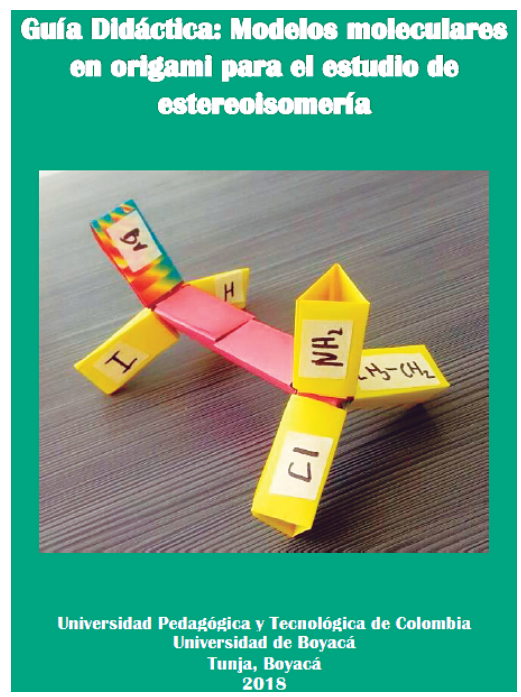

Figure I. Didactic guide cover
Next, in Table 3, the coherence matrix is related to the four workshops carried out for the experimental groups, taking into account the didactic guide designed. In Annex 2 is one of the most significant activities of the didactic guide, in this one there were exercises of molecular modeling in origami and proposal of the two-dimensional projections of these models.

Table 3. Coherence matrix about the workshops.

\begin{tabular}{|c|c|c|}
\hline Workshop & Topic & Activities \\
\hline I & $\begin{array}{l}\text { Isomers } \\
\text { Structural isomers }\end{array}$ & $\begin{array}{l}\text { a) Elaboration of the molecular } \\
\text { model of Carbon. } \\
\text { b) Three-dimensional representa- } \\
\text { tion in two dimensions. } \\
\text { c) Preparation of Structural } \\
\text { Isomers }\end{array}$ \\
\hline 2 & $\begin{array}{l}\text { Stereoisomer, } \\
\text { enantiomers and } \\
\text { chirality }\end{array}$ & $\begin{array}{l}\text { a) Identification of chiral and } \\
\text { achiral molecules. } \\
\text { b) Enantiomers of Limonene. } \\
\text { c) Configuration of an amino } \\
\text { acid with a chiral center. }\end{array}$ \\
\hline 3 & $\begin{array}{l}\text { Diasteroisomers } \\
\text { Configuration of } \\
\text { diastereoisomers. }\end{array}$ & $\begin{array}{l}\text { a) Diasteroisomers in amino } \\
\text { acids. } \\
\text { b) Diasteroisomers of glucose. } \\
\text { c) Stereoisomeric relations. }\end{array}$ \\
\hline 4 & Meso Compounds & $\begin{array}{l}\text { a) Identification of meso } \\
\text { compounds. } \\
\text { b) and c) Planes of symmetry } \\
\text { in meso compounds. }\end{array}$ \\
\hline
\end{tabular}

The third phase: "evaluation phase", where a final test was developed, which evaluated all the groups, including the control group. This test consisted of seven questions that evaluated two categories, the first: "identification of molecular representations", relating the bidimensional and three-dimensional character of the matter. The second category evaluated: "conceptualization of stereoisomerism", such as chirality, configuration of chiral centers, diastereoisomers and meso compounds. Annex 3 contains the final test, where questions 1,3 and 5 correspond to the first category and questions 2, 4, 6 and 7, to the second category.

In order to carry out research in education, it is important to have reliable and validated instruments, as mentioned by Galicia, Balderrama and Edel (2017). Taking into account the above, the validation of the evaluation instruments - diagnostic test and final test - of this investigation was carried out through a procedure known as: "Expert Judgment". The methodology used for this was of a qualitative type and consisted in providing the tests to three teachers, experts in the area of chemistry and didactics 
of chemistry, of the Pedagogical and Technological University of Colombia, who made some recommendations or suggestions, prior to the implementation of these instruments. It is to be considered that the validating teachers, reviewed the tests twice, in order to refine the tests used. Table 4 lists the academic profile of the evaluators, as well as the criteria evaluated during the validation process for the diagnostic and final test of the investigation.

It should be added that for each question of both the diagnostic test and the final test, it was evaluated according to a rating scale characterized below in table 5 .

\section{Results}

\section{Diagnostic test}

Then, Figure $I$ and 2 show the percentages of results obtained for the categories in each rating scales of the four study groups. These results of the diagnostic test allowed analyzing the weaknesses and conceptual strengths of each group, according to the evaluation categories.
In figure 2, the percentage of response for each assessment scale for category I of the diagnostic test is related. This shows that for the excellent and outstanding rating scale, group $C$ stood out for having results of 22,5 and $52,5 \%$, as well as group $B$, with an assessment of $8,3 \%$ and $45 \%$, respectively. For the same scales group $A$, that is to say the control group, obtained the lowest percentages: $3,2 \%$ and $24,2 \%$, respectively. In the insufficient and deficient scale group A obtained the highest percentages compared to the other groups, that is, $54,8 \%$ and $17,7 \%$, in the case of group $D$, for the Insufficient assessment scale it obtained results of $0 \%$, however for the deficient scale it presented $47,5 \%$.

Figure 3 shows the percentage results obtained for category 2 of the diagnostic test. For this category it is possible to analyze that group C with $40 \%$ obtained better results for the excellent rating scale, compared to the other groups. Regarding the outstanding rating scale, group B obtained higher results with $16,6 \%$, compared to the other groups. For the insufficient scale, group $A$ obtained the highest percentage with $43 \%$, unlike group $D$, which obtained the lowest percentage for this scale

Table 4. Results validation process for evaluation instruments.

\section{Validator Profile}

Validator

Professor of the Degree in Natural Sciences and Environmental Education (UPTC).

Research areas:Teaching chemistry and education sciences.

Validator 2

Chemistry Teacher (UPTC)

Research areas: Organic chemistry, analytical chemistry and physico-chemistry.

Validator 3

Chemistry Teacher (UPTC)

Research areas: Organic chemistry, biochemistry, analytical chemistry.

\section{Evaluation criteria}

Final test
The test is relevant, adjustments are recommended.

The test is relevant, does not require adjustments.

The test is impertinent.

The test is relevant, adjustments are recommended.

The test is relevant, does not require adjustments.

The test is impertinent.

The test is relevant, adjustments are recommended.

The test is relevant, does not require adjustments.

The test is impertinent.

Table 5. Assessment scale for each test question.

\begin{tabular}{ccccc} 
Rating scale & Abbreviation & Vigesimal interval & Description \\
Excellent & E & {$[8-10]$} & The question was answered correctly. \\
Outstanding & O & {$[6-8)$} & The question was partially, reaching a satisfactory level. \\
\hline Insufficient & I & {$[4-6)$} & The question was answered partially, but did not reach a satisfactory \\
level.
\end{tabular}




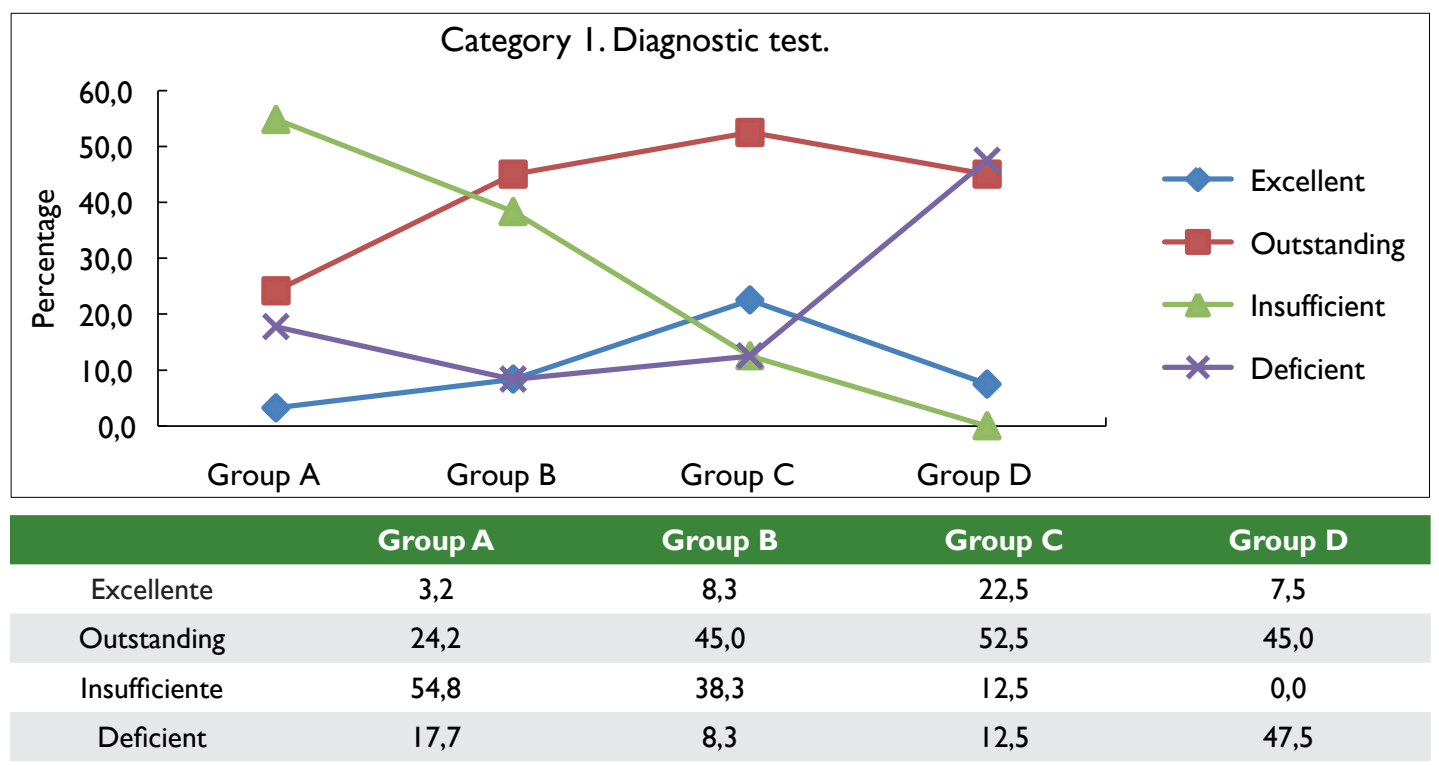

Figure 2. Percentage of results by rating scales for category I of the diagnostic test.

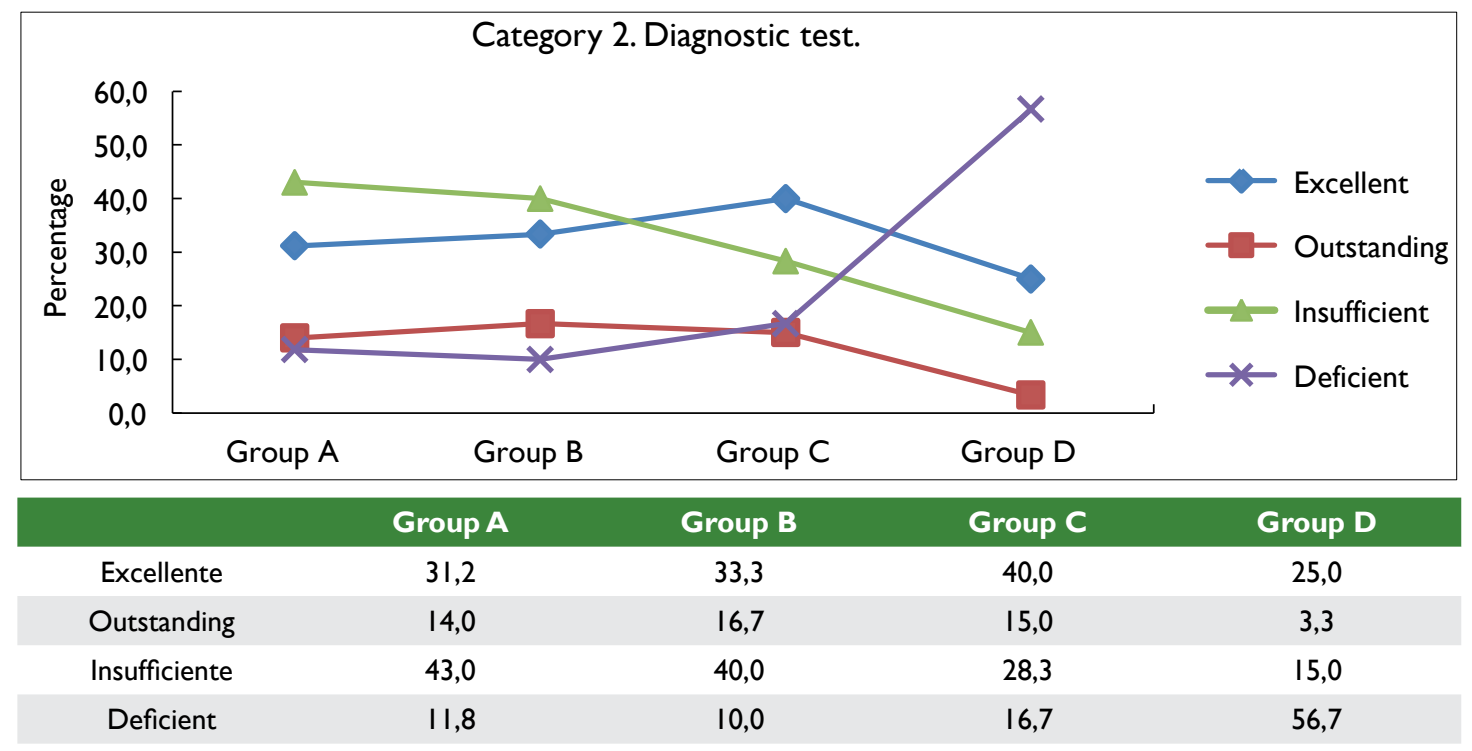

Figure 3. Percentage of results by rating scales for category 2 of the diagnostic test.

with $15 \%$; finally, in the case of the deficient scale, it was identified that group $D$ obtained the highest percentage of results with $56,7 \%$.

Taking into account the previous results, it is possible to consider that the research participants, at a general level, use molecular representations of two-dimensional type, however, they present difficulties taking into account the degree of iconicity, that is, the degree of realism of a structure compared to the object it represents (Pro, 2003). This characteristic must precisely be related to the threedimensionality of matter; therefore, Flamini and Wainmaier (2012) recommend the use of molecular models in order to improve spatial visualization.
On the other hand, regarding the conceptual association of the students, there is evidence of a limited mastery of concepts such as: molecular representation, threedimensionality, isomers and stereoisomers. Simoes, Campos and Marcelino (2013), consider that the lack of mastery for this type of concepts is due to the pedagogical focus addressed in a traditional division of the curriculum between organic chemistry and inorganic chemistry. The same authors point out that these branches follow the main classification system, for organic chemistry consists of constitutional isomer and spatial isomer or stereoisomer, for the inorganic chemistry, its classification is limited exclusively to coordination compounds. 


\section{Final test}

Figure 4 shows the percentage of the results obtained in category I of the final test, for each of the groups and the established evaluation categories. This highlights that for the excellent valuation scale group C obtained $53,3 \%$, the highest percentage being. However, in the case of groups $B$ and $D$, favorable results were also obtained for the control group, with $48,9 \%$ and $33,3 \%$ for the category in question, a similar case occurred on the outstanding scale, where experimental groups B, C and D obtained better results with $40 \%, 38,3 \%$ and $33,3 \%$, respectively. In relation to insufficient and deficient scales, present the highest results with $57 \%$ and $1 \mathrm{I}, 8 \%$, respectively; In the case of the deficient category, the control group was the only one that obtained classified responses within the deficient valuation scale.

In this category, difficulties of molecular visualization were evidenced, mainly for the control group, where the three-dimensional representations of the molecules were erroneously projected and at the same time, compositional errors of the material were committed. The experimental groups had greater mastery in the realization of black wedges to indicate that the link is in front of the plane and they perfectly identified the dashed lines, noting that the link is behind the plane, thus shaping the threedimensional structure of the material.

In the case of groups B and C, which obtained higher percentages of responses in the excellent and outstanding rating scales, it was identified that to make the threedimensional representations, first they make the semideveloped formula of the composed; this process involves the transformation of a mental representation through an operation, to produce a new representation, as Briggs and Bodner (2005).

Another important aspect to highlight is the difficulty presented by group A (control group) to assign the configurations in the chiral centers of the molecular representations; for Perez (2008), this is because the lower priority substituent is not always projected opposite to the observer, therefore, students experience inconveniences to mentally operate the chiral center until this condition is fulfilled.

Figure 5 shows the percentage of the results obtained for category 2 of the final test. These results highlight that group $\mathrm{B}, \mathrm{C}$ and $\mathrm{C}$, that is, the experimental groups obtained the highest results for the excellent rating scale, with $75.8 \%$ and $68.8 \%$ and $62.5 \%$, respectively. In relation to the control group, it is noteworthy that for the outstanding valuation scale, it obtained the highest percentage, with 31.5\%; however, for the insufficient and deficient scales it obtained the highest percentages with $16.1 \%$ and $15.3 \%$ respectively, exceeding the results of the experimental groups that did not exceed $5 \%$.

For this category it was evidenced that in the experimental groups, the students related concepts about stereoisomers from spatial visualizations of the matter. Authors

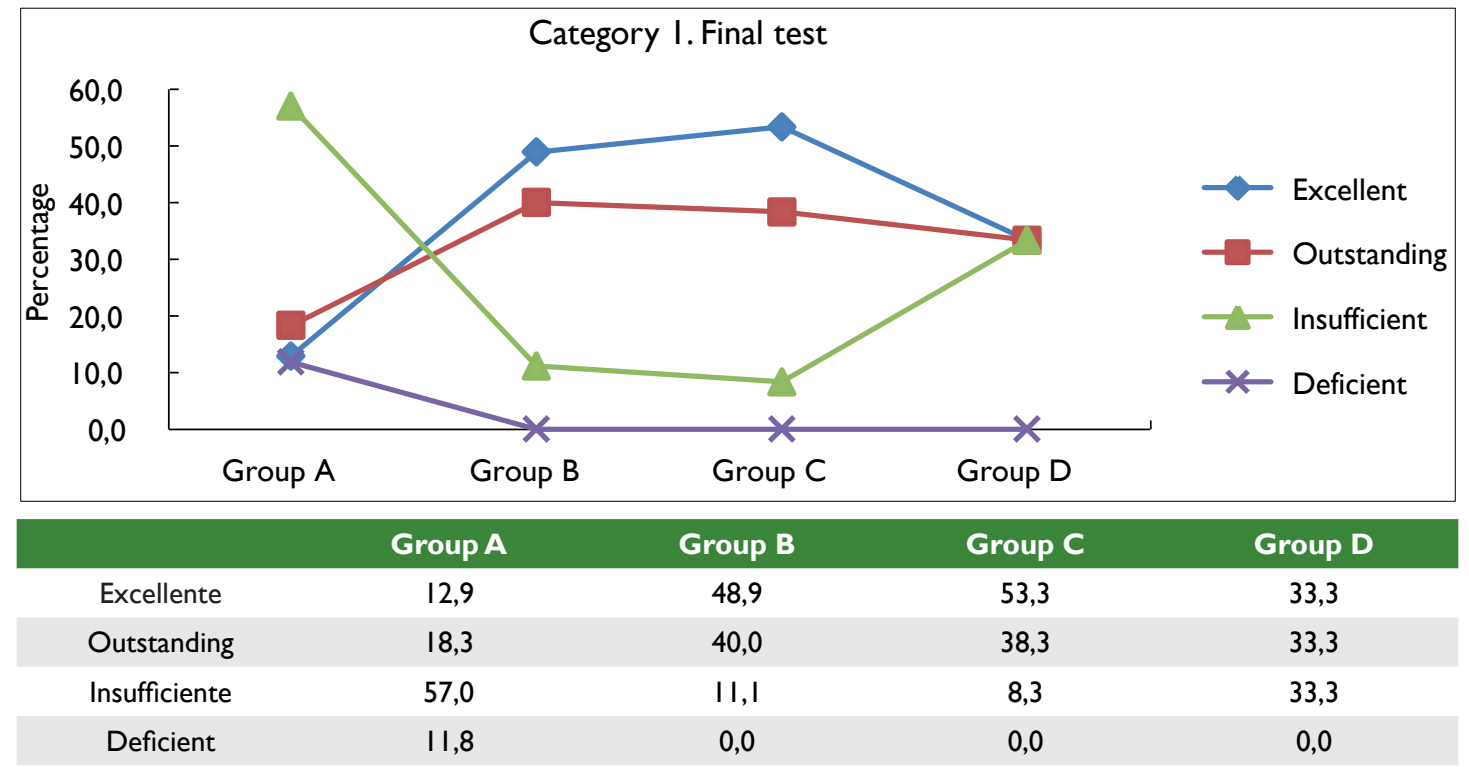

Figure 4. Percentage of results by rating scales for category I of the final test. 


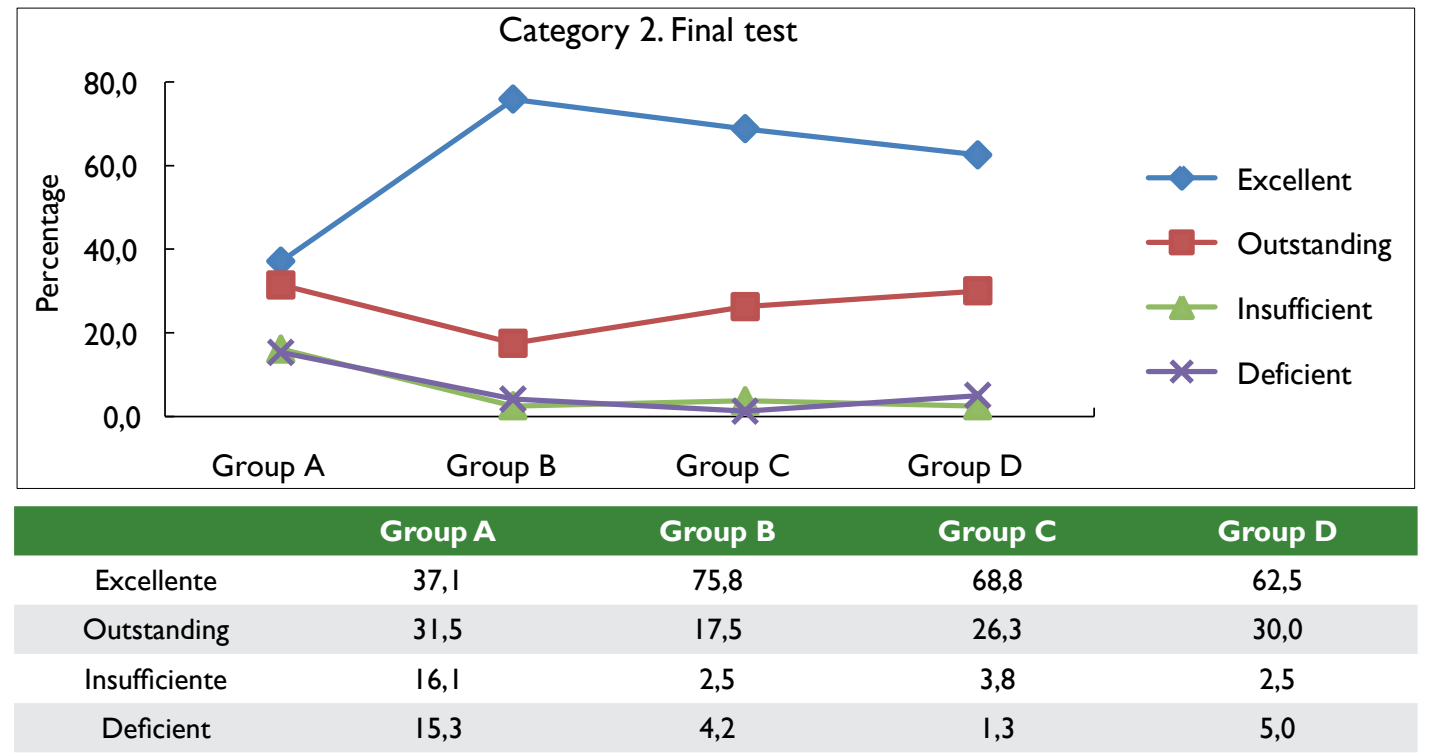

Figure 5. Percentage of results by rating scales for category 2 of the final test.

such as Wu and Shah (2004), resumed by Cadavid (20I3) argue that this process of molecular visualization contributes to an internal representation that requires a physical model, for this reason students who interacted with molecular models in origami, obtained better results in the scales of excellent and outstanding valuation.

The identification of chiral centers and their configuration, was another significant contribution of the didactic strategy, when contrasting the results obtained between the control group and the experimental ones. Authors such as Pérez (2008), Lima (20I5), Rezende, Amauro and Rodrigues (2016) have developed didactic strategies to improve the understanding of these concepts. Hernández (20I5) and Castro (2007) agree that chirality is one of the fundamental pillars of life, because most biological processes have a high degree of enantioselectivity, which can produce different biological effects at the cellular level or organismic.

It is important to highlight the ability of students to make mental turns of molecules at a certain angle, establishing spatial relationships that require the mental rotation of molecules, either in two dimensions or three, this type of process is described by Pribyl and Bodner (1987) as a relationship is spatial and molecular visualization. In this sense, Gardner (200I) points out that the mental realization of turns in space implies a task of demanding mental transformation that must be strengthened in the teachinglearning processes.
Gilbert (2010) considers that one of the most important competences for the learning of sciences is spatial visualization, but there are complex concepts that refer to abstract levels, which means the need to intervene in the teaching-learning process, for transform and bring the contents into a didactic version that can be understood by the students (Buchelli \& Marín, 2009). Based on this, it is considered that the methodological process of this research allowed a transformation on stereoisomeric contents, emphasizing stereoisomers with stereogenic centers, since through the design and implementation of a guide with origami modeling activities, they read content of knowledge (conceptual) into teaching content.

From the didactic transposition theory, the difference between the knowledge taught and the erudite knowledge is legitimized, carrying out two transpositions as such, one external and one internal (Alfaro \& Chavarría, 20I2), the external one is related to the contents curricular of the subjects in which this research was directed (Organic Chemistry and Biochemistry) and the internal character was constituted by the participation of the research teachers by adapting changes of knowledge to teach about stereoisomers. Finally, it is recognized that molecular models in origami were an indispensable resource in the didactic transposition since they favored the development of spatial visualization skills, transforming commonly oriented contents from a flat and two-dimensional profile to one of three-dimensional representation, by manipulating models physical molecular manipulatives. 
For the quantitative analysis of the final test, the $\mathrm{Chi}^{2}$ test of goodness of fit was applied, this nonparametric test was used in order to analyze the distributions of the observed results and the theoretical results in the categories of each test: the diagnostic test and the final test. For these hypotheses, the following hypotheses were proposed:

Null hypothesis (Ho): The number of observed results is statistically equal to the expected, where $p \geq 0,05$. It should be added that the value of 0,05 is a value established according to the $95 \%$ confidence level.

Alternate hypothesis (Ha): The number of results is different from the statistically expected at least on some rating scale, where $p<0,05$.

Then, in table 6 the data obtained in the Chi ${ }^{2}$ test for category I of the final test are described, when comparing the observed results with the expected results for each group in the assessment scales, it was determined that $p<0.05$; therefore, the null hypothesis is rejected and the alternative hypothesis is accepted, which shows that the amount of data compared is statistically different in at least one category, such as it can be seen in the case of group $\mathrm{D}$, when comparing the observed data with the expected data in the excellent, outstanding and insufficient scale, the same frequency was obtained; however, in the deficient scale, the frequency obtained in the observed data is different from that in the expected data.

Table 7 shows the values obtained for the $\mathrm{Chi}^{2}$ test of goodness of fit for category 2 of the final test, in which the observed data is compared with the expected data in each of the rating scales, where the values $p$ for group $A$ it was 0.0004 and for groups $B, C$ and $D$ it was 0 , these values being less than 0,05 , therefore the alternative hypothesis is approved and the null is rejected, because the amount of observed data is statistically different from what was expected.

In consideration of the values of $p$ (level of significance) obtained in the $\mathrm{Chi}^{2}$ goodness-of-fit test, for the results of the final test, in relation to the rating scales used for each category, the null hypothesis was rejected and the alternate hypothesis was accepted, indicating that the amount of expected results (data) is different from the statistically expected results, at least on a rating scale, where the level of significance $p$ it was less than 0,05 .

Table 6. Chi ${ }^{2}$ test of goodness of fit for category I of the final test.

\begin{tabular}{|c|c|c|c|c|c|c|c|c|c|c|c|}
\hline \multirow[b]{3}{*}{ Group } & \multicolumn{9}{|c|}{ Chi' ${ }^{2}$ of goodness of fit for category I of the final test. } & \multirow[b]{3}{*}{ Value $p$} & \multirow[b]{3}{*}{$\mathrm{Chi}^{2}$} \\
\hline & \multicolumn{4}{|c|}{ Data observed by group. (Rating scale) } & \multicolumn{5}{|c|}{ Expected data by group. (Rating scale) } & & \\
\hline & $E$ & 0 & 1 & D & f & E & 0 & I & D & & \\
\hline A & 12 & 17 & 53 & 11 & 93 & 23,25 & 23,25 & 23,25 & 23,25 & 0,0000 & 51,6 \\
\hline B & 44 & 36 & 10 & 0 & 90 & 30 & 30 & 30 & 30 & 0,0000 & 51,0 \\
\hline C & 32 & 23 & 5 & 0 & 60 & 20 & 20 & 20 & 20 & 0,0000 & 38,9 \\
\hline D & 20 & 20 & 20 & 0 & 60 & 20 & 20 & 20 & 20 & 0,0001 & 20,0 \\
\hline
\end{tabular}

Table 7. Chi ${ }^{2}$ test of goodness of fit for category 2 of the final test.

\begin{tabular}{|c|c|c|c|c|c|c|c|c|c|c|c|}
\hline \multirow[b]{3}{*}{ Group } & \multicolumn{9}{|c|}{$\mathrm{Chi}^{2}$ of goodness of fit for category 2 of the final test. } & \multirow[b]{3}{*}{ Value $p$} & \multirow[b]{3}{*}{$\mathrm{Chi}^{2}$} \\
\hline & \multicolumn{4}{|c|}{ Data observed by group. (Rating scale) } & \multicolumn{5}{|c|}{ Expected data by group. (Rating scale) } & & \\
\hline & $E$ & 0 & I & D & $\mathbf{f}$ & $\mathbf{E}$ & 0 & I & D & & \\
\hline A & 46 & 39 & 20 & 19 & 124 & 31 & 31 & 31 & 31 & 0,0004 & 17,8 \\
\hline B & 91 & 21 & 3 & 5 & 120 & 30 & 30 & 30 & 30 & 0,0000 & $17 \mid, 8$ \\
\hline C & 55 & 21 & 3 & I & 80 & 20 & 20 & 20 & 20 & 0,0000 & 93,80 \\
\hline D & 50 & 24 & 2 & 4 & 80 & 20 & 20 & 20 & 20 & 0,0000 & 74,80 \\
\hline
\end{tabular}




\section{Conclusions}

Taking into account the results obtained in the diagnostic test, it was determined that for category I, called "Perceptions about molecular representations "groups B, C and $D$, obtained better response percentages in the excellent assessment scales, these being, $8,3 \%, 22,5 \%$ and $7,5 \%$, respectively; in the case of the outstanding rating scale, the aforementioned groups obtained the best results, with $45 \%, 52,5 \%$ and $45 \%$, respectively In relation to the insufficient scale, group A presented the highest results with $54,8 \%$ and in the deficient scale, group $D$ obtained $47,5 \%$. Therefore, it was determined that mainly group A did not prove correct appropriation of molecular representations, taking into account the results obtained in the insufficient and deficient categories.

Groups A, B and C obtained better percentages of results in the excellent and outstanding rating scales for category 2 of the diagnostic test, suggesting that these groups have greater mastery in the identification of molecular representations. However, in relation to the insufficient valuation scale, group $A$ obtained the highest percentage with $43 \%$, and for the deficient scale group D obtained $56,7 \%$, being the highest percentage in relation to Groups $A, B$ and $C$.

The results obtained in the final test, determined that the didactic strategy implemented, contributed to the didactic transposition of contents in stereoisomer and the development of visuospatial skills, this taking into account that the experimental groups (Groups B, C and D) obtained the percentages higher response rates for the excellent rating scale, being: $48,9 \%, 53,3 \%$ and $33 \%$ in category I called: Perceptions about molecular representations "and for category 2:" Identification of molecular representations "obtained percentages response of $75,8 \%$, $68.8 \%$ and $62,5 \%$ On the other hand, the control group (group A) presented the highest percentages for the insufficient assessment scales of the two categories, with $57 \%$ and $16,1 \%$; likewise, it obtained the highest percentage in the scale of poor valuation of the two categories, with II,8\% and $15,3 \%$, respectively.

In relation to the quantitative analysis through the $\mathrm{Chi}^{2}$ test of Goodness of Adjustment and the values of significance $(p)$, obtained in relation to the percentages of results obtained and those expected, it was determined that these did not follow a statistical distribution in relation to the sample used, therefore, the null hypothesis was rejected and the alternative hypothesis was accepted.

\section{Acknowledgments}

The article is a outcome of a research named: Transposición Didáctica de Estereoisomería en Moléculas Orgánicas Mediante Modelos Moleculares en Origami, Universidad Pedagógica y Tecnológica de Colombia.

\section{References}

Alfaro, C. \& Chavarría,J.(2012). La Transposición Didáctica: un ejemplo en el sistema educativo Costarricense, Uniciencia, 21 , I53-168.

Briggs, M., \& Bonder, G. (2005). A model of molecular Visualization. Visualization in Science Education, 90-105.

Briones, G. (1998). Investigaciones o Diseños Experimentales, Revista Electrónica de Estudios de Opinión, 2, I-18.

Buchelli, G. \& Marín, J. (2009). “Transposición didáctica: bases para repensar la enseñanza de una disciplina científica. I parte", Revista Académica e Institucional de la UPCR, 85, 17-38.

Cadavid, V. (20l3). Relaciones entre la metacognición y el pensamiento visoespacial en el aprendizaje de la estereoquímica, Universidad Autónoma de Manizales, Manizales, Colombia. Recuperado de http://repositorio.autonoma. edu.co/xmlui/handle/ I / /82//86

Castro, M. (2007). Nuevas contribuciones de la cromatografia electrocinética con detección UV y de la espectrometría de masas en el campo de las separaciones quirales, Universidad deAlcalá, Barcelona, España. Recuperado de https://ebuah. uah.es/dspace/handle/I00 I7//578?locale-attribute=es

Chevallard.,Y.( (99I). La transposición didáctica: del saber sabio al saber enseñado, Buenos Aires Argentina, Aique.

Cook, T. \& Campbell, D. (1979). Quasi-experimentation. Design and analysis issues for field settings. Chicago, IL: Rand McNally.

Flamini, L. \& Wainmaier, C. (20I2). Representaciones Moleculares: Reflexiones Sobre Su Enseñanza, Actas III Jornadas de Enseñanza e Investigación Educativa en el campo de las Ciencias Exactas y Naturales, 307-316. Recuperado de http://www.memoria.fahce.unlp.edu.ar/trab_eventos/ ev.367I/ev.367I.pdf

Galicia, L., Balderrama, J. \& Edel, E. (20I7). Validez de contenido por juicio de expertos: propuesta de una herramienta virtual. Apertura, 9, 42-53. http://dx.doi.org/10.1838I/ Ap.v9n2.993 
Gardner, H. (200I). Estructura de la mente: teoría de las inteligencias múltiples. Colombia: Fondo De Cultura Económica. https://utecno.files.wordpress.com/2014/07/howard_ gardner_-_estructuras_de_la_mente.pdf

Garrido, B. (2007). "Papiromoléculas: modelos moleculares de papiroflexia para el estudio de la geometría molecular". Aprendizaje Activo de la Física y la Química. Madrid, 27-34. Recuperado de https://dialnet.unirioja.es/servlet/ libro? codigo $=375164$

Gilbert, J. (2010). Modelling, Modeles, and Visualization. Asian Pacific Forum on Science Learning and Teaching, II(I) PP. 4-I2.

Hernández, D. (20I5). La quiralidad en las biomoléculas, del espacio al planeta Tierra, Síntesis Catalítica Asimétrica: Una visión integral de los enantiómeros (pp. 17-18), México: Centro de Investigaciones químicas, Universidad Autónoma del Estado de Morelos. Recuperado de https://dialnet. unirioja.es/descarga/articulo/4678464.pdf

Hernández, R., Fernández, C., \& Baptista, P. (20 I0). Metodología de la investigación. México, D.F: McGraw-Hill.

Lima, M. (2015). Proposta de jogo químico como estratégia didática no ensino a distância abordando o conteúdo de estereoquímica, Universidad de Federal do Rio Grande do Norte, Río de Janeiro, Brasil. Recuperado de https://repositorio. ufrn.br/jspui/handle/I 23456789/20594

Pérez, A. (2008). La equivalencia entre las paridades de los intercambios de dos sustituyentes y las reflexiones especulares, en la determinación de la quiralidad de átomos tetraédricos: ¡Una demostración con espejos!, Educación Química, I, |46-I5I.
Pérez, M. (2015). Los métodos de investigación en educación. En A. Pantoja (Ed) Manual básico para la realización de tesinas, tesis y trabajos de investigación, España: Madrid EOS.

Pérez,V. (2013). Separación Enantiomérica ylo Determinación de Compuestos de Interés Medioambiental por Metodologías Analíticas Electroforéticas y Cromatográficas Innovadoras, Universidad de Alcalá, España. Recuperado de https:// ebuah.uah.es/dspace/handle//0017/20I8I

Priblyl, J. \& Bodner, G. (1987). Spatial ability and its role in organic chemistry: a study of four organic courses, Journal of Research in Science Teaching, 24, 229-240.

Pro, M. (2003). Aprender con imágenes. Barcelona: Ed. Paidós.

Rezende, G.,Amauro, N. \& Rodrigues, G. (2016). Desenhando Isomeros ópticos, Conceitos Científicos em Destaque, 38, | 33- | 40. http://dx.doi.org//0.5935/0 |04-8899.201600|8

Simoes, J., Campos, A. \& Marcelino., C. (20I3). El uso de situaciones problema para la enseñanza superior de isomería en química inorgánica. Avances en Ciencias e Ingeniería, 4, 6I-68.

Verret, M. (1975). Transposition Didactique. París: Librairie Honoré Champion. 


\section{ANNEXES}

\section{ANNEX 1.}

\section{DIAGNOSTIC TEST}

I) What molecular representations do you know?

2) Write the molecular, empirical, condensed and Kekulé representation of the following molecule:<smiles>CCCCCC</smiles>

3) Draw the types of carbon atomic hybridization.

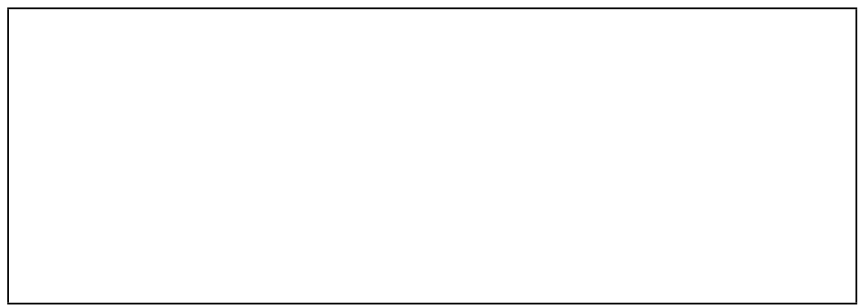

4) Select the three-dimensional representation of an alkane with 6 Carbon atoms.<smiles>CCCCCC</smiles><smiles>CCCC(C)C</smiles>
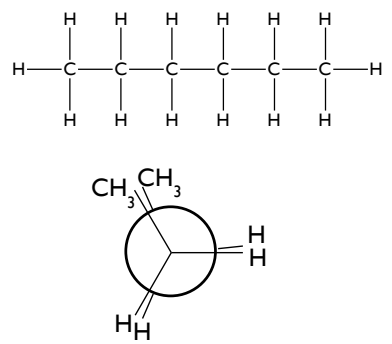

5.What is an isomer? What are stereoisomers?

\section{ANNEX 2.}

\section{THREE-DIMENSIONAL REPRESENTATION IN TWO} DIMENSIONS.

Indications: represents the molecular models in origami, by wedge or easel, according to the view of the observer, as shown in the photographs.
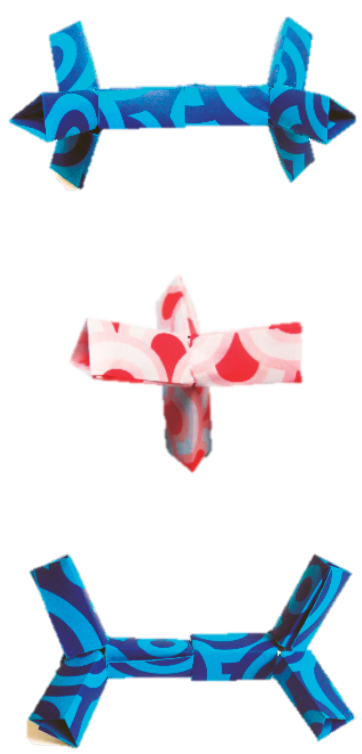

Analyze!

- What was the molecule that was most difficult to represent? Why?

- How do molecular models allow you to position yourself spatially?

- If the molecular models that appear in the photographs are rotated $180^{\circ}$, will their twodimensional representation be different from what you did in the activity? 
ANNEX 3.

\section{FINAL TEST}

I.Why are these compounds not the same?
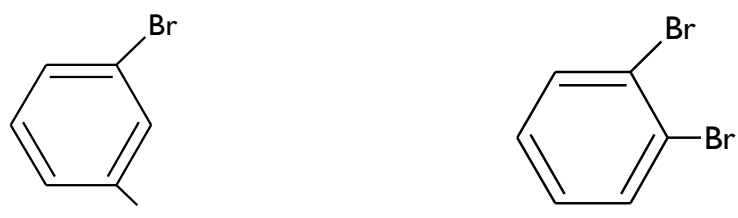

2.What are stereoisomers?

3. Represent on the sawhorse the 2-methylbutane molecule.

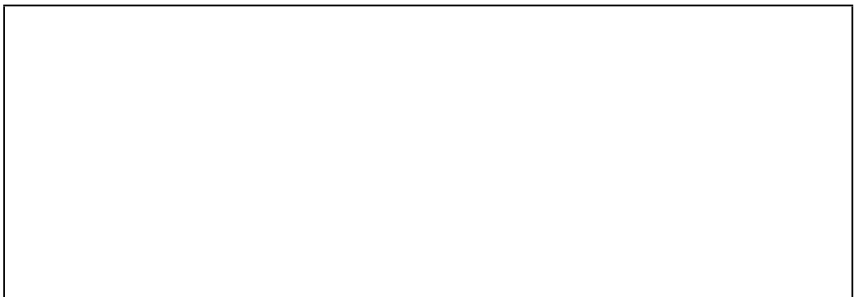

4. Select the chiral compounds and indicate with an asterisk $(*)$ the asymmetric carbon.
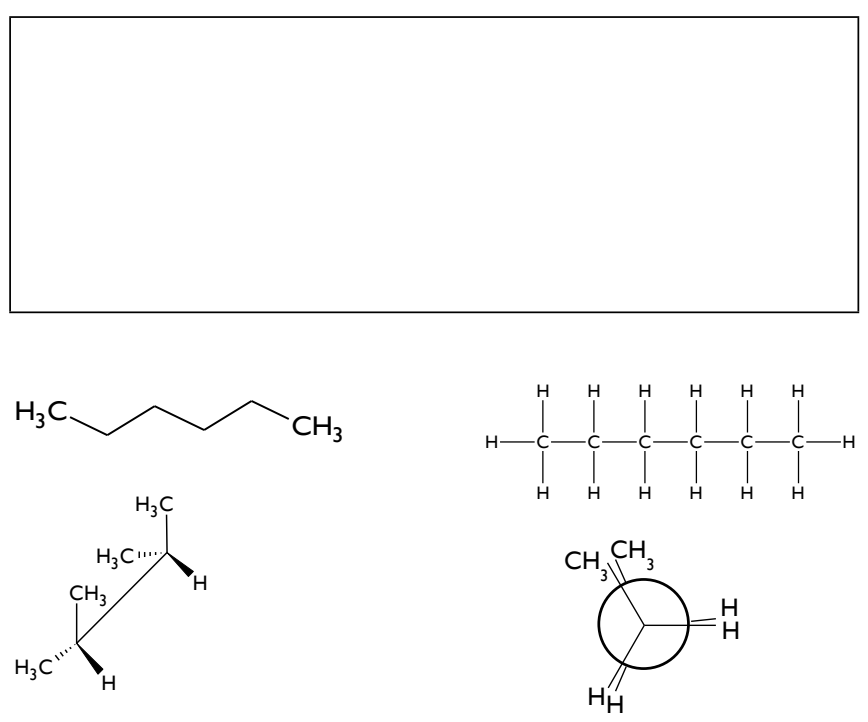

5. It represents the mirror image of the following compounds and determines their configuration ( $R$ or $S$ ).
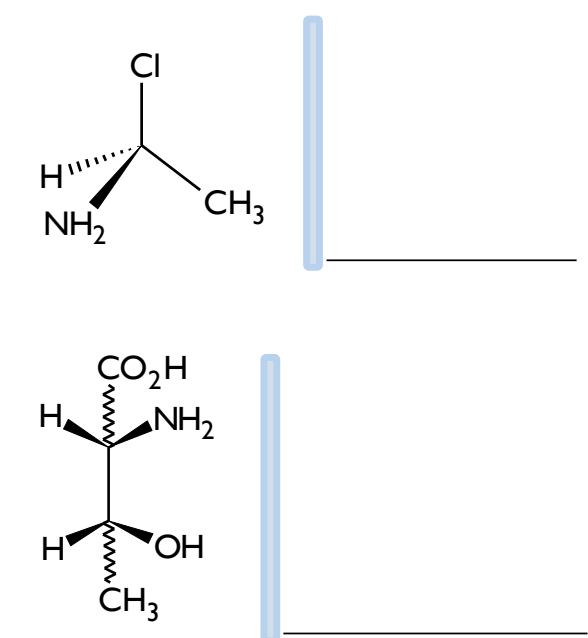

6. Find the diastereomers of the following molecule:<smiles>C[C@@H](Cl)C(Cl)Cl</smiles>

7. By rotating the next molecule $180^{\circ}$, will you get a stereoisomer of the meso type? Justify your answer.

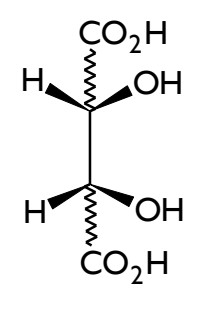

2R, $3 S$ 